\title{
Editing Errors
}

Giovanni Paolo Maggioni

Università di studi del Molise, Italy

In mediaeval Latin literature, the presence of editorial mistakes in the original text is not rare. These errors can spread in the whole manuscript tradition, not descending from the existence of a common archetype, but directly from the original exemplar. Some of them are not the result of the bad work of a single scribe, but the blame for them seems to be on the author. But this abnormal presence causes some troubles in the philologist's work. How can we recognize them? How can we distinguish them from scribal mistakes? And is it possible to assume that a reputed medieval author made veritable blunders and keep these oddities in a modern critical edition? This paper wants to show how a comparison between the sources and the recensio are irreplaceable tools for the analysis of the variants in the manuscript tradition of medieval Latin texts.

\section{Reliability of a Text}

Across the centuries, in the history of literature, philologists, scholars and simple readers have been faced with some fundamental questions facing a written text. Is this text reliable? Is it a perfect copy of the original work of the author?

The question was particularly crucial before the invention of print, when every manuscript was different from the others, but even today it is rather important: for instance, in I990, in the first Italian edition of Ken Follett's The Pillars of the Earth, I found a certain saint mentioned as Symeon the 'Stylist', ${ }^{\mathrm{I}}$ a strange holy figure that evidently was more plausible for a Milanese publisher than the ancient saint, Symeon Stylites. In this case the correction is rather simple for a philologist, even if I can

This lecture was given on 20 November 2012 at Stockholm University.

How to cite this book chapter:

Maggioni, G. P. 2016. Editing Errors. In: Crostini, B., Iversen, G. and Jensen, B. M. (eds.) Ars Edendi Lecture Series, vol. IV. Pp. 26-49. Stockholm: Stockholm University Press. DOI: http://dx.doi.org/IO.I6993/baj.c. License: CC-BY 4.0 
not exclude that some Italian readers today believe in the existence of a strange early saint patron of Versace or Prada. Fortunately, a case of this kind is rather rare, but it highlights some of the most important skills required for a philologist, that include knowledge of the language, knowledge of the subject and, last but not least, knowledge of the editorial context that produced the actual printed text (in this case, the lack of a qualified copy-editor).

Thanks to the work of many philologists, we all know how many advantages critical editions can offer to modern scholars, by removing errors that were produced through innumerable copies over the centuries. But sometimes even a critical text can surprise us, proposing a reconstruction that does not seem to correspond to our consideration of the author. For example, in the critical edition of the Golden Legend, we read, absurdly, that the Saracens sacked the Isle of Lipari in the fourth century: 'Anno domini CCCXXXI Saraceni Siciliam inuadentes...'. ${ }^{2}$ But Iacobus de Voragine, as well as being a hagiographer and a preacher, was also a historian who, besides the Golden Legend and the sermon collections, also wrote a historical Chronicle of Genoa. Nevertheless, the critical editor decided to print in the text the date ' 33 I' instead of the correct ' 83 I', even though this emendatio would have been an easy correction, since in the text the word that immediately precedes the year is 'Domini' of Anno Domini, usually shortened in ' $\mathrm{D}$ ', which is also the Latin number for 500: the origin of the mistake is thus clarified, and the correct century could have thus been easily restored with good reason. Similarly, we can read in the edition of the Life of Theodora, a ninth-century hagiographical text, that the saint found a man eating a beast, hominem comedentem a bestia (or, even more literally, 'a man eating from a beast'), where the beast is a crocodile. ${ }^{3}$ I will get back to these 'errors' later.

\section{Philology and errors ${ }^{4}$}

Of course, philologists can make, and actually make, errors in their work, a fact that we experience every day, but in these pages I wish to deal with the particular case of faulty originals. My hypothesis is that an author can produce an original text with some unwanted errors in it. These mistakes force philologists, in a manner of speaking, to blemish the reputation of the author, fixing a number of 'errors' on a printed page of a modern edition. Here I want to discusss some particular cases in which an imperfect, but authorial, text was written and given to a scriptorium to be copied when its form was still in need of corrections. 


\section{An apparent contradiction: definition of error in philology and Lachmann's method}

Let us start with a definition of error in philology: an error is something (a term, a phrase, a chronological notation) that contradicts the culture of the author, as we know it. ${ }^{5}$ So, when we read in a manuscript some error of this kind, we suppose that the text has been modified by somebody else. Beside this term with this rather negative connotation, I will use here also the positive term 'innovation' and the more neutral term 'perturbation', to mean something that is not to be ascribed to the author, but to the conscious will or the unwanted carelessness of a copyist. ${ }^{6}$

If we admit that such an error can be in the original text itself, so the method with the name of Karl Lachmann, ${ }^{7}$ as formulated by Paul Maas, ${ }^{8}$ seems to collapse, since we do not have, apparently, any reliable reference points to reconstruct the lines of the manuscript tradition. If a perturbation could be caused by the author himself, then the notion of authorial error poses a difficult problem for the Lachmannian method. The question can be solved if we add another requirement to the definition of error: an error is not only what contradicts the culture of the author, but also what is incompatible with the author's actual work of composition and edition. We can spot occasions for this kind of error before, during and after what we usually define as the process of composition.

\section{Instances of 'authorial' errors}

\section{A. Before composition}

Medieval texts have a particularly strong relationship with their sources and with the canons of their peculiar literary tradition. These sources were often copied more or less literally from existing manuscripts, which naturally had their own errors and their textual perturbations. In facing these errors the author, or his collaborators, could behave as a philologist would, correcting ex ingenio the source, but it is possible, especially if a (tired or careless) collaborator copied the source, that the errors accidentally spread from the sources to the new text. This contamination, wherein the scribe switches from the exemplar to the source for a quotation, gives us important clues about the relationship between the text, its sources and the manuscripts actually used, but also muddles the reconstruction of the tradition and the definition of the critical text. ${ }^{9}$ 


\section{B. During composition}

During composition, most of the authorial errors are due to a sort of doubling, or even a multiplication, of the key elements in the process of composition: the writer and what we call his original text.

\section{The author}

Sometimes during the composition of the text the author was not alone, but he was helped by more or less skilled secretaries who could do a more or less good job. Normally, the author himself did the veritable editorial work and took care of revising and inserting the parts formerly transcribed by his secretaries. But sometimes it could happen that his review has been careless or superficial and that some error made by the secretary sneaked into the text. These errors could be simple copying mistakes, which could be made by anyone and could often be corrected by everyone, but they could also be more serious ones: for instance, the confusion between emperors or popes with almost the same name or other chronological mistakes. If, on behalf of the author, the secretary attached some additional notes, adding them in a piece of parchment inserted between the pages or transcribed in the margins of the page, every misunderstanding of the insertion marks could produce perturbations that could forever affect the text, its history and its tradition.

Translations from Greek to Latin or from Latin to vernacular languages are another example of perturbations to the original text, mainly when more than one person took part in the process of defining the text. The translator could share the same mother tongue as that of the original text, but he could be not so skilled in the target language of the translation and could thus need the help of another person with complementary skills. The communication and the division of work between them could be different: the translator could write a first version in the space between the lines, and the reviewer could correct it and eventually copy it; or one person could read the original text, while a second one was actually translating and writing it. Here textual perturbations could be caused by a bad handwriting or by a mishearing, mixed again with weariness or inattention.

\section{The original text}

But the largest number of authorial perturbations is caused by the instability of the original. The most common case is when there is more than one version of the text. Some time after the first draft the author 
could have reedited it without completely rewriting the text, but using an existing manuscript. Normally the author corrects the errors of this copy and adds some parts, with additional notes in the margins or on a piece of parchment, eliminates other parts by deleting them and occasionally transcribing alternative parts in the margins or on additional pages. But once more, the author or his secretary could be tired or occasionally careless. Copyists' errors in the manuscript of the first version could slip unnoticed in the new text and become authorial, because the author himself used them, inserting them in the second version of the text and giving them an authorial worth. In the same way, once again, extensive additions, transcribed on one or more additional pages could be copied in the wrong position, misunderstanding the insertion point. And again it is possible that the author did not notice these errors, causing their diffusion in the original text.

\section{After composition}

After composition, in most cases, text perturbations are caused by copyists. ${ }^{\circ}$ Bad copyists can add their errors to the text, and good copyists can reproduce it faithfully. But for what concerns the authorial errors, we can note that good copyists can perturb the original text correcting it, while dumb ones can preserve what they found in their model.

Once again, even in this case, it is possible for the author to cause perturbations. For example, he could chase existing copies, trying to eliminate some authorial error. ${ }^{\mathrm{II}} \mathrm{He}$ can correct some errors, but not others, perturbing the lines of the textual tradition and confusing the philological recensio.

There is, if possible, something even worse: the author can himself transcribe a copy of his work, as a gift for a friend, for example. And, it is the case of Boccaccio, he can be a good editor but a terrible copyist, ${ }^{\mathrm{I}}$ making more errors than a professional copyist and producing an autograph worse than other witnesses for the number of mistakes, despite a good mise en page. One can easily understand how many troubles such an autograph can cause to the philologists and to their efforts in reconstructing the original text.

\section{The Text-Complex: Sources/Author/Original/ Archetype /Copies / Readers}

At this point, a couple of questions can be raised: how can Lachmann's method be useful for a reconstruction of the lines of the textual tradition? Can a hypothetical reconstruction be any better than a real extant manuscript? Without doubt, the answers depend on our idea of text. 
It is clear that the first Italian edition of Pillars of the Earth is a text, a solid existing book. But its literary worth is limited. It witnesses only to the sad decay of a glorious Italian publisher. The translation is of limited value in reconstructing Ken Follett's original work and reveals little concerning the translator's qualifications, since the error we pointed out above is an evident hyper-correctionism, i.e. a lectio facilior made by somebody in the publishing house. The first Italian edition is surely useful to the reconstruction of the history of the text, since the Italian translation is certainly one part of the history of Ken Follett's text. But without the knowledge of the original text, its worth is limited. The knowledge of the original form for a correct evaluation of the history of the text is especially necessary in medieval literature, in which there are very often no secure boundaries to define an author, distinguishing him and his work from other authors and their works, and to recognize a text distinguishing it from its sources. For the Middle Ages it is possible to talk of a communication system where sources, authors, copyists, readers, preachers, audiences have a part. For example, this system is particularly evident for hagiographictraditions in preaching (seeFigure I). In such cases, for a philogical study of the texts, of their history, of their transmission, of their tradition and of their reception, the idea of original/originary text has an extreme importance, allowing us to link and to anchor the communication system to a form that permits a critical evaluation of all the other forms and a correct reconstruction of the text's history. Surely we could not define the author's text without examining every copied witness, but neither could we understand the importance of the copy as it was actually read, without a (at least hypothetical) reconstruction of the original. Besides this, we have also to consider that every existing manuscript is a carrier of its own variants as homoteleuta. For this reason, a critical examination of the text is needed for any actually existing manuscript.

Nowadays we are often facing the theories of the so-called New Philology, some of which seem to privilegiate existing witnesses (the manuscripts) rather than a critically reconstructed text, considered as an abstract and theoretical entity. But it seems obvious to me that to evaluate correctly any variant we need to know the original starting point of the textual history, i.e. the authorial text. Beside this, we point out that any witness needs corrections and text formatting (interpreting abbreviations, uniforming graphies and so on), and also this slight and indispensable human intervention creates something that never existed before. This preference for what is immediately visible (and the consequent devaluation of the critical work of the intellect) is a trend that we can 
Original hagiographic text (s. II - XIII)

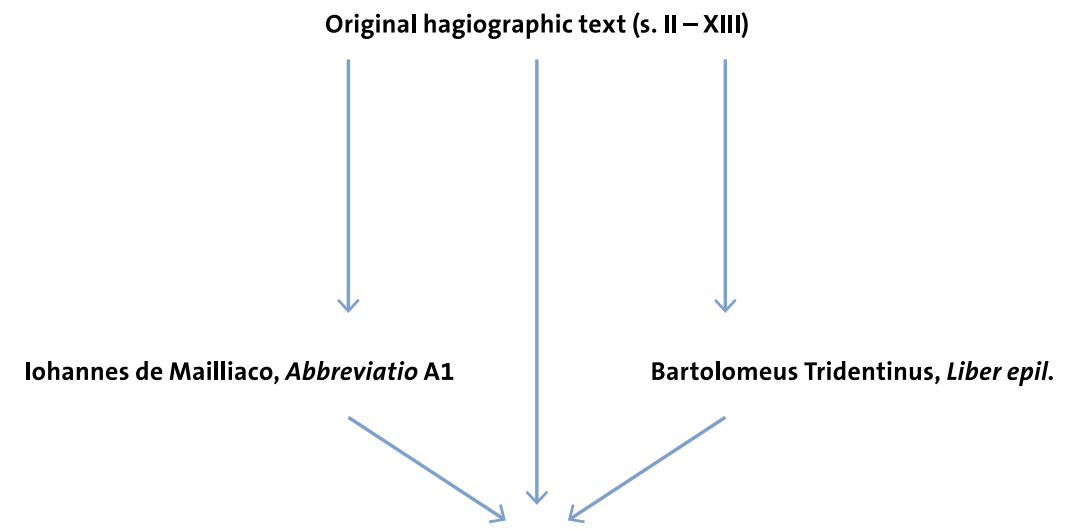

Model sermons $\quad$ lacobus de Voragine, Legenda LA1

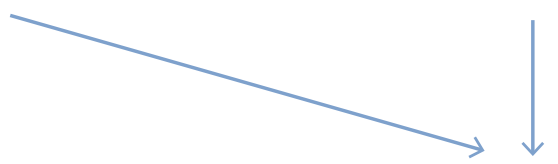

Preacher

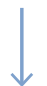

Audience (s. XIII-XVI)

Figure 1. Hagiographical Texts in the Dominican Communication System.

recognize in contemporary society and in its global connection, where it is easier to find the digital reproduction of a manuscript than a critical edition, and where, in general, any assessment is seen as something unnatural and therefore considered with suspicion.

\section{Importance of the recensio and of a Critical Evaluation of the Tradition}

For these reasons we cannot forget the lesson of Karl Lachmann: primum recensere ! $^{13}$ It is necessary to draw the lines of the manuscript tradition and evaluate the text and its history, starting from the sources and following the developments of the text and the work of the copyists in the scriptoria. We need as complete a reconstruction as possible to discriminate between the work of the author and the unintentional perturbations and the intentional corrections due to copyists' activity, since we need to recognize every variant that not only can not be ascribed to the culture of the author, but also can not have been generated by 
that author's techniques of composition, by his/her approach to the tradition and by his/her use of the sources.

\section{How to recognize authorial errors}

\section{Recensio}

To recognize mistakes and imperfections due to an author's work, we need to have a clear idea of the lines of the manuscript tradition and we need the best possible recensio. The authorial errors are generally present in all the branches of the tradition, since in most cases they spread from the original, unless the author generated them with a later direct intervention on an exemplar in a particular branch of the tradition. We have to keep in mind that authorial errors are very often errors that can be corrected, and that any copyist could eliminate. A recensio that is as complete as possible allows us a better judgment about the presence of an error in the original or in the archetype.

\section{Original versus archetype}

It is also necessary to consider the existence in the manuscript tradition of a common archetype from which all the existing witnesses could depend. A hypothesis of authorial errors could be contradicted by the existence of a model, placed/occurring just at the roots of the manuscript tradition, affected by at least one error spread in all the descending branches. If there is no such archetype and the manuscript tradition descends from the original itself, it is more probable that some mistakes are authorial errors due to the method of composition of the text, if they spread without clear reasons in different branches of the tradition.

\section{Knowledge of the sources}

A third condition that could help us to recognize authorial errors is the study of the tradition of the sources: if a textual error is present also in the former tradition of its source, it is probable that the same error passed in the authorial text, mainly if the text was composed with the help of secretaries who could be more or less qualified or interested to correct the source.

\section{Knowledge of the method of composition}

Last, but not least, as we have already said, we must try to reconstruct the method of composition of the text: for instance, if the author has worked 
alone or with one or more secretaries; if the text is a translation, and in that case if there was more than one translator, when the competences were split between several qualified persons with particular skills in Greek, Latin or vernacular languages.

\section{How to Manage Errors: by Keeping or Eliminating Them?}

When the textual critic encounters authorial errors, the 'author's will' (i.e. his original intention) cannot be the only reference point for the definition of the text. In my opinion the reconstruction must propose a sort of photography of the original just before the copy. If the author did not notice the error in the sources, or the imperfect work of his secretaries, we must keep that error in our edition. For instance, going back to the Vita Theodorae just quoted, in the case of the expression invenit hominem comedentem a bestia, I chose to keep the active participle against the witness of some manuscripts that attested the grammatically correct form hominem comestum. Since this text was translated from Greek, we may explain the error by the fact that the translation was made by a Greek who did not know how translate the aorist active participle in Latin, a language where the past participle is normally passive. The original form in the Greek text read: $\tau \rho \omega \varphi$ $\mu \varepsilon v o v$

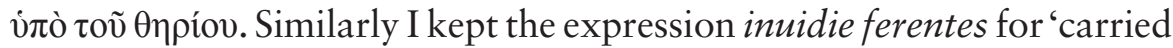

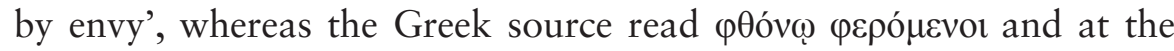
same time I kept specular forms as cognita que passa est, for 'knowing what she suffered', where the perfect participle, passive, corresponds to the Greek active participle $\gamma$ voṽ $\sigma \alpha$. Here is the entire passage in parallel columns:

Vita Theodorae, Greek Text, BHG I $727-9^{\text {I4 }}$

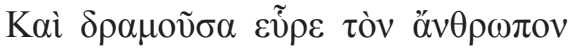

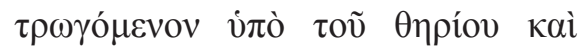

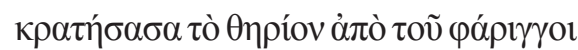

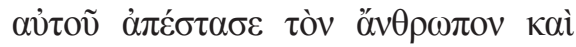

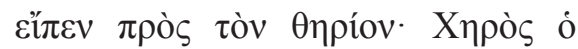

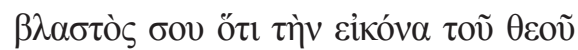

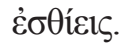

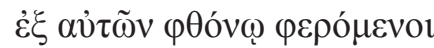

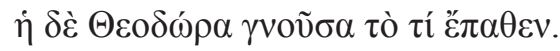

Vita Theodorae, Latin Text, BHL $8070^{15}$

Et accurrens inuenit hominem comedentem a bestia et apprehendens bestiam a faucibus eius detulit hominem et dixit bestie: «Exsiccetur guttur tuum, quoniam imago dei comedisti». ${ }^{16}$

quidam ex illis inuidie ferentes ${ }^{17}$ Theodora uero cognita que sibi passa est. ${ }^{18}$ 
In the first passage we can also note that imago is used as accusative form: probably the Greek model for the translation had the variant $\varepsilon$ it $\delta \omega \lambda \mathrm{ov}$, neuter, and we can suppose that the translator used the correspondent term imago as neuter as well. Another possibility, suggested by Barbara Crostini, is that the phrase 'imago Dei' was considered a kind of standard expression, and the translator did not think of inflecting the noun to fit the grammatical structure of his particular sentence. In the second example we find a perfect correspondence between $\varphi \theta$ óv $\omega$ and inuidie. By the way, all these three examples show that the final result was a language that can not exactly be called Ciceronian Latin.

\section{Examples from Thirteenth-Century Legendaries}

To illustrate what I said before, I wish to take into consideration some authorial errors in the original text of the Golden Legend and in other hagiographic collections of the thirteenth century. These errors concern hagiographical traditions and affect names, dates, and historical circumstances; they are errors that are spread in the whole manuscript tradition and that do not descend from the existence of a common archetype, but directly from the original: consequently these errors are not the result of the bad work of a single scribe, but the blame for them seems to be on the author, even if for us it is hard to believe so. For example, we can hardly allow that Iacobus de Voragine, a Dominican friar who became archbishop of Genoa, could confuse Egypt with Ethiopia for St Matthew's apostolate, or assume that Saracens sacked a Mediterranean isle in $33 \mathrm{I}$.

I wish to show how some misunderstandings and some mistakes that have entered in the text and in its main tradition were produced in the special circumstances of a collective editorial work that, nevertheless, made it possible to achieve encyclopedic works like the Golden Legend or the other thirteenth-century Dominican collections. It was an enormous, difficult task that, even if done by qualified persons, needed effective editorial control. But evidently sometimes this supervision seems to have been imperfect or even lacking.

David D'Avray defined the Dominican cultural production in the thirteenth century as an attempt at mass communication. ${ }^{19}$ This massive production of instruments for a better preaching was the product of a complex work in which many persons were involved. First, there were no real borderlines between the different Dominican hagiographers: the chapters of Iohannes de Mailliaco's Abbreviatio 
in gestis sanctorum are used in the Speculum Historiale of Vincent of Beauvais, and both the Speculum and the Abbreviatio are literally copied in Iacobus de Voragine's Golden Legend, without quoting the names of either Iohannes or of Vincent. Both these texts passed from one work to the other, quite physically, through pieces of parchment of various dimensions that could be inserted between the pages or added at the end of some copy or pecia. The outline in Figure 2 illustrates the complexity of such relationships between these legendaries and their sources, taking as an example the chapter De Sancto Bartholomeo in the Golden Legend and its sources.

Secondly, all these collections are themselves collective works. All these authors (Iohannes of Mailliaco, Vincent de Beauvais, Iacobus de Voragine), directed veritable teams of secretaries, to whom they entrusted tasks such as finding sources and copying them in the new text versions. This collective editorial work was a cause of errors that we find in the original texts of these collections. And we can incidentally observe how much human errors can interfere in the composition and in the assembling of a text. ${ }^{20}$

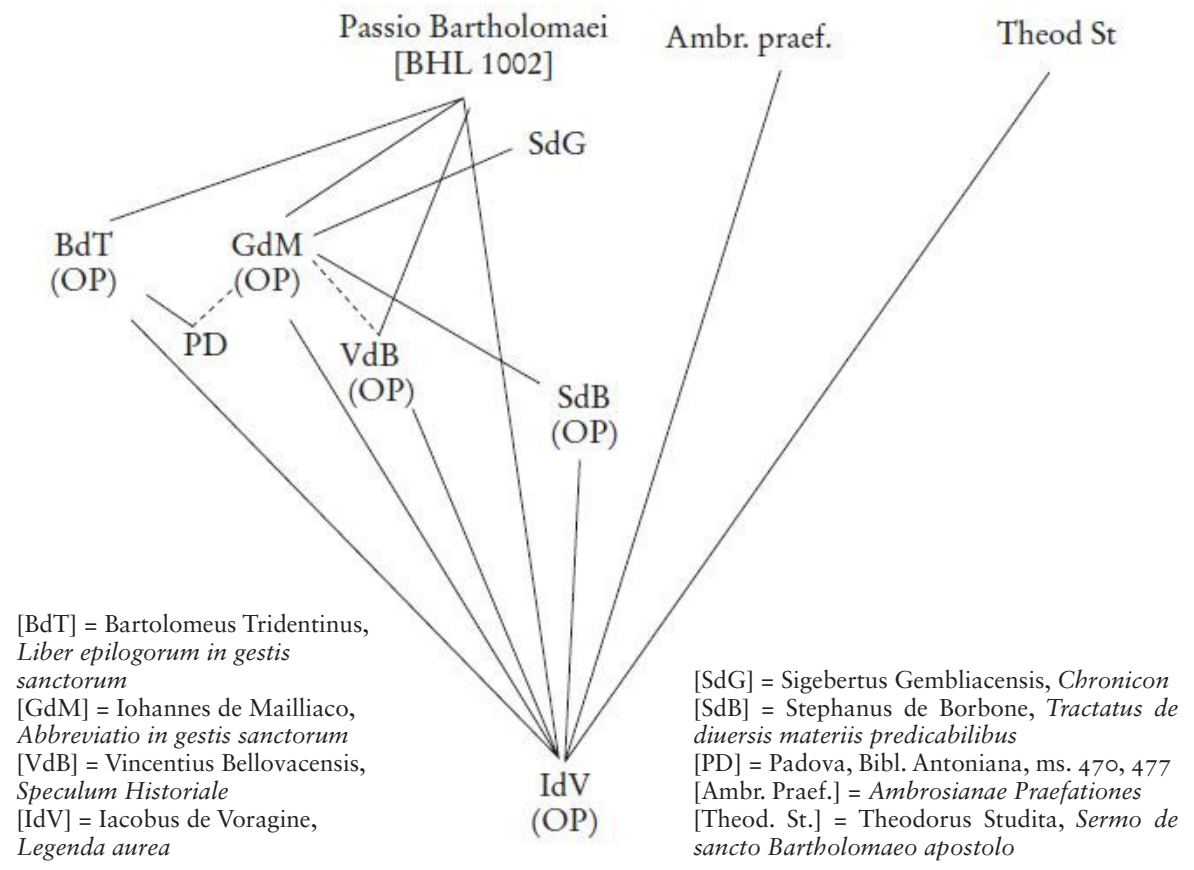

Figure 2. The Sources of the Chapter De sancto Bartholomeo of the Golden Legend 
How did these secretaries or compilers work? The direction was naturally in the hands of the author. He decided which saints and which texts were to be included in his book; he decided also the plan and the structure of each chapter. Then he assigned individual tasks to his secretaries. After that, he collected and assembled the material, inserted interlinear or marginal notes, corrected mistakes, interpolated or cut out passages that might be very different in length (a single word or a whole chapter or an entire series of chapters). Finally, he could copy this rough draft, or give it to a scribe to produce what now, after many centuries, we can call the 'original' text.

Any passage of this complex collective editorial work can be an occasion of errors that we can detect in the manuscript tradition. First, we can recognize some errors that were present in the manuscript tradition of the sources and that were merely copied later on: for example, in the chapter De septem Dormientibus in the Golden Legend we read of the proconsul Antipater, a recent arrival in the city. ${ }^{2 \mathrm{I}}$ But no proconsul with this name is quoted in Gregory of Tours' narration of the legend, ${ }^{22}$ nor

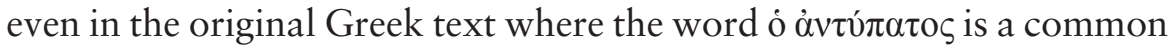
noun for the governor of the city. ${ }^{23}$ The proper name Antipater in the Golden Legend and in its sources is an error caused by what can be described as a kind of dittography, probably derived from an interlinear note, formed from the translation (proconsul) and the transliteration (Antipatus) $^{24}$ of the same Greek term. This error is also present in the Passio septem dormientium edited in the Biblioteca Casinensis. ${ }^{25}$

Similarly, in the Golden Legend, in the chapter De sancto Matheo, we read that a magnet can attract rings but also straws (festucas in Latin). ${ }^{26}$ Here the words et sucinis (transl.: 'and in amber objects') were omitted in the manuscript copy of the source (i.e. St Jerome's Commentarii in euangelium Matthei $)^{27}$ that was actually used for the compilation of the chapter of the Golden Legend and this error too remained unnoticed. Again in the same chapter the apostle Matthew, converting the king of Ethiopia Egyppus, leads to the true faith totam Egyptum. ${ }^{28}$ And, as we have seen before, in the chapter De sancto Bartholomeo, ${ }^{29}$ the Saracens invaded Sicily in AD $33 \mathrm{I}$ : the Roman numeral for $83 \mathrm{I}$ begins with $\mathrm{D}$, as the standard abbreviation for Domini, and this coincidence caused the disappearance of five centuries. Also in this case the mistake remained unnoticed by the secretary and by the author and/or corrector. However, we can point to the origin of these errors, since we know the source (Iohannes de Mailliaco or Jerome or the original text of the Seven Sleepers) and we know that those errors have been produced before 
the original, in the manuscript tradition of the source. $3^{30}$ Consequently we can conclude that in the original text of the Golden Legend these 'errors' were present, since it is extremely improbable that all these textual perturbations have been produced independently in the source and in the manuscript tradition of the Golden Legend. These errors, like those that a secretary made in copying the source and which eluded the control of the author/corrector, are common to all the most ancient manuscripts and the editor chose to keep them in the text of the critical edition. And the critical text of Iohannes de Mailliaco's Abbreviatio in gestis sanctorum, the main source of the Golden Legend, confirms the presence of imperfections in the original text: here we can find notes like 'Require de hoc...', ${ }^{3}$ or blank spaces left for a dating that was never inserted, ${ }^{32}$ or errors like a confusion between Emperor Constantine and Emperor Constans (who lived three centuries later), ${ }^{33}$ a mistake that Iohannes de Mailliaco, who wrote a universal chronicle, ${ }^{34}$ could not commit, but that his secretaries made.

In the examples shown above, the errors affect single words. But the special features of the editing work for the Dominican hagiographic collections of the thirteenth century have produced perturbations in the history of the text that are more evident in magnitude. In particular we have to consider the fact that all these works had different authorial versions. In other words, Iacobus de Voragine, as Jean de Mailly and Vincent de Beauvais before him, repeatedly revised his text, for example when he became aware of other sources or when he was elected archbishop and above all as his readers changed: there are more Golden Legends and the latest is not a collection written just for preachers, but it is a work that can be appreciated also by lay readers that could be looking for stories not only edifying, but also interesting and inspiring. I have drawn the outlines of the evolution of the history of the author and of his text in Figure 3.

To prepare a new and more complete Golden Legend, Iacobus de Voragine took an existing manuscript of the older version and, once again, he integrated it with marginal or interlinear notes and he (or his secretaries) inserted bigger parchment pieces and quires for longer passages and chapters. Once again, copying this rough draft was an occasion for errors. First, since the existing manuscript used to make the new edition had its own errors that, once again, remained unnoticed; secondly, since the copy of the added texts produced other errors; and in the third place, since this new rough draft formed by a sort of bundle of manuscript folia with marginal 


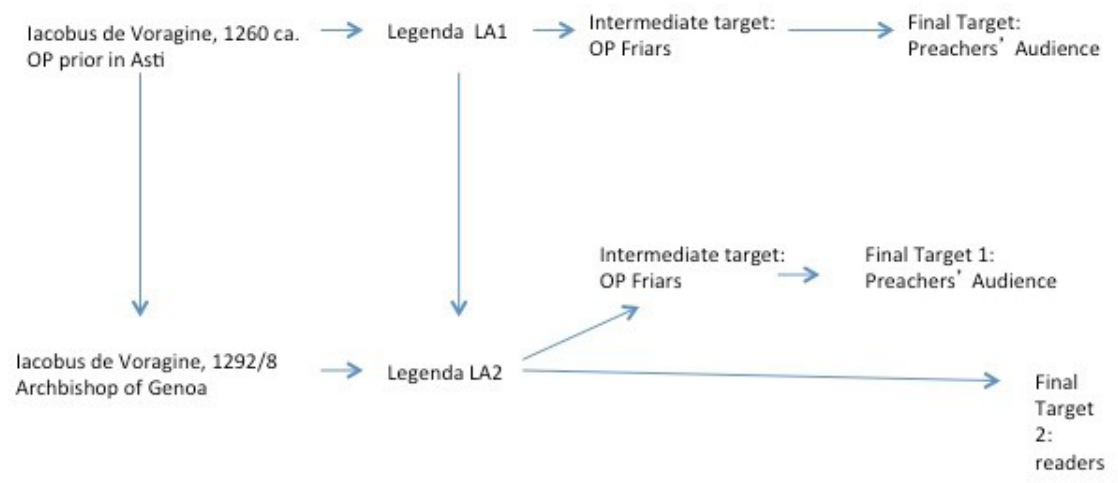

Differences:

Insertion of new chapters, Insertion of narrative parts, insertion of chronological data, insertion / removal of docrinal parts, insertion of explanatory notes for geografical terms and rare words.

Figure 3. Iacobus de Voragine and the Evolution of the Golden Legend

notes and pieces of parchment inserted between the pages or at the end. This material form was the cause of bigger errors that concerned the wrong position of big text parts or the wrong position of whole chapters. Since the Golden Legend follows the ecclesiastical year, these displacements are without doubt evident anomalies. For example, an evident displacement of a note is visible in Graesse's edition (the most important nineteenth-century edition) in the chapter on Saint Pelagius, where the history of King Theodericus and the philosopher Boethius is placed in the seventh century, between King Dagobert and Bede: ${ }^{35}$ a copying mistake that forced Ryan, the English translator, to interpret the Latin expression per idem tempus, with the more probable, but much less faithful, Earlier than all this. ${ }^{36}$

To show even more macroscopic examples, in the Golden Legend, as we know it, in all the most ancient manuscripts and in the critical edition, the chapter of Saint Mamertinus is between Saint Lupus and the Birth of the Virgin. ${ }^{37}$ But Saint Mamertinus is honored on 20 April, while the dies natalis of Saint Lupus is the first of September and the Feast of the Birth of the Virgin is the eighth of September. In the English translation (made on the nineteenth-century uncritical text of Theodore Graesse), the list of the chapters is not better, since Saint Mamertinus is 
between Saint Lupus and Saint Giles,,$^{38}$ who are both honored the first of September.

This incongruence is easy to explain: ${ }^{39}$ in the first version of the Golden Legend all the chapters between Saint Giles and the Birth of the Virgin were still missing. For the new version, Iacobus de Voragine asked a secretary to copy some new chapters from the Abbreviatio in gestis sanctorum: these new chapters were Saint Savinianus $\left(29^{\text {th }}\right.$ of August), Saint Lupus ( $\mathrm{I}^{\text {st }}$ September) and, last, Saint Mamertinus $\left(20^{\text {th }}\right.$ April). Probably the secretary copied these three chapters on a single quire and this quire was inserted whole in the rough exemplar in a place corresponding to the $\mathrm{I}^{\text {st }}$ of September. Maybe an insertion sign or an advisory note was written at the beginning of Saint Mamertinus, to indicate the right place were the chapter was to be inserted, but for some reason the entire quire and all the three chapters were copied in succession, while Mamertinus remained there, in September, five months after his dies natalis.

The strange position in the Golden Legend of the chapters of Saint Basil and Saint John the Almsgiver seems to have a similar origin. ${ }^{40}$ Both chapters are between Saint Vincent $\left(\mathbf{2 2}^{\text {nd }}\right.$ January) and the Conversion of Saint Paul ( $25^{\text {th }}$ January), a period that has nothing to do with the date of their cult ( $\mathrm{I} 4^{\text {th }}$ of June and $\mathrm{I}^{\mathrm{th}}$ of November respectively). Their position on the other hand is near to the feast of another saint, a hierarch of the Byzantine Church: Saint John Chrysostom, who is honored on the $27^{\text {th }}$ of January. The three saints (Basil, John the Almsgiver and John Chrysostom) are absent in the main source of Jacobus, Iohannes de Mailliaco's Abbreviatio, but are present in the second main source, the Liber Epilogorum of Bartholomaeus Tridentinus. ${ }^{4 \mathrm{I}}$ So it is possible that here, once again, the cause of the displacement may be a single quire with three different chapters, whose marks for insertion were neglected by the final scribe.

The case of Saint Fursa is similar: usually Fursa is honored on the I $6^{\text {th }}$ of January, his dies natalis, or sometimes on the $9^{\text {th }}$ of February, the day of his translation. His position in the Golden Legend is between Saints Cosmas and Damian (2 $7^{\text {th }}$ September) and Saint Michael $\left(29^{\text {th }}\right.$ of September). ${ }^{42}$ There is no hagiographic reason for this, but there is an editorial one. This chapter is actually a sort of exemplum to illustrate a paragraph of the following chapter, on Saint Michael. In this chapter Iacobus, after the usual compendium about the cult traditions, deals with the reasons we should honor the angels: they are our guardians, 
our servants, our brothers and fellow citizens and, as in the case of Saint Fursa, they carry our souls to heaven. What we read as an independent chapter dedicated to Saint Fursa is actually a short abstract of the original Vita Fursei, ${ }^{43}$ from which only the passage concerning the struggle between the angels was extrapolated. These angels want to carry Fursa's soul into Heaven, against the devils, who on the contrary want to carry it to Hell. Once again, the text has probably been transcribed on a piece of parchment and put together with the quire dedicated to Saint Michael and the angels, probably with a sign of insertion on it. But, for some reason, this fragment, probably a single parchment folium, was copied before, as an independent chapter, by a careless copyist.

In the Golden Legend a chapter dedicated to Saint Margaret, also called Pelagius or Pelagia (or Marina with an evident synonymic transposition between pelagus and maris), is inserted after Saint Pelagia, with the name De sancta Margarita dicta Pelagius in a position corresponding to the $8^{\text {th }}$ of October. ${ }^{44}$ However, there is no tradition of a cult that can justify this collocation, since Saint Margaret (or Saint Marina) is honored on I 8 June, according to some manuscripts of the Roman Martyrology attributed to Jerome. ${ }^{45}$ In the Golden Legend we actually find a chapter dedicated to Saint Margaret on the $18^{\text {th }}$ of June as well. ${ }^{6}$ The reason of this doubling is that two versions of the same legend have been transcribed into the Golden Legend. The first is the legend of Saint Marina that comes from Bartholomaeus Tridentinus' Liber epilogorum where we find it on the $\mathrm{I} 8^{\text {th }}$ of June; ${ }^{47}$ the second one is the same legend, but under the name of Saint Margaret called Pelagia in October and comes from Iohannes de Mailliaco's Abbreviatio in gestis sanctorum..$^{8}$ But Iohannes inserted it in his legendary as a simple appendix of his chapter concerning Saint Pelagia, that is correctly on the $8^{\text {th }}$ of October, with an introductory note where he explained that in this appendix he recorded the life of a virgin not less noteworthy for habits and very similar as to the name. ${ }^{49}$ In the Golden Legend, a reworking of the whole chapter was copied, but, since the introductory note was omitted, the second part was considered as an independent one, worthy of a title, particular heading and illumination.

Other traditions in the Golden Legend have been created through the confluence of the two main sources of the legendary - the Abbreviatio in gestis sanctorum and the Liber epilogorum - and this has been the cause of other - sometimes surprising- doublings. A good example is the number of John the Baptist's fingers honoured in Saint-Jean-de-Maurienne, in 
France, on the Alps near the Italian border. For Bartholomaeus Tridentinus, the finger is one and it is the forefinger with which he pointed at the Saviour, ${ }^{5}$ according to John Beleth's Summa de ecclesiasticis officiis. ${ }^{51}$ Also for Iohannes de Mailliaco, who follows Gregory of Tours ${ }^{52}$ and Sigebert of Gembloux, ${ }^{53}$ the finger is one, but it is the thumb that a Savoy matron miraculously obtained after many prayers: for him the index finger is in some church in Rome. ${ }^{54}$ In the Golden Legend, the fingers in the church of Saint-Jean-de-Maurienne are two: the forefinger and the thumb, since the two passages are copied in succession..$^{55}$

In these pages I have presented some mistakes that affect the original text of the Golden Legend. Some of them are very little and some more evident, but they have a common origin: an imperfect supervision of the author who did not remedy the incidents caused by the rough complexity of the original and its difficult copy process, not correcting, for example, the misunderstandings of insertion signs for different saints in the same quire or for interlinear and marginal notes.

Of course, all these errors are unintentional and do not suit the culture of Iacobus de Voragine, preacher and historian. Nevertheless these errors have entered into the Western hagiographic tradition. For example, Cardinal Baronius in the sixteenth century put the feast of Saint John the Almsgiver on the $23^{\text {rd }}$ of January in the Roman Martyrology, presumably following the authority of the Golden Legend..$^{5}$ In other words, the Golden Legend was deemed to be authoritative for Saint John the Almsgiver and therefore created a new tradition. That same authority transformed a minor tradition, the apocryphal narration of Seth and the sprout of the tree of knowledge, in the main European tradition about the Holy Cross, through the preaching of the mendicant orders.

The above are some examples of authorial mistakes. They have been recognized through a former study of manuscript tradition and text history, which allowed to see how the author actually worked and to understand in which way the sources were actually used. In this way, mistakes that did not seem to be ascribed to the author's culture become compatible with that author's working methods. They were indeed present in the original, authorial text and they are not subsequent copyists' modifications of that text, wanted or unwanted.

A final remark: since these errors have been produced by an immediate and accidental cause that has deformed the text forever, in a manner of speaking we can see here an example of the influence of randomness in the human creative process. 


\section{Notes}

I. Ken Follett, I pilastri della terra (Milano: Mondadori I990), at p. I49: 'Il capitolo incominciò con la lettura di un brano su san Simeone lo Stilista, del quale ricorreva la festa'.

2. Iacopo da Varazze, Legenda aurea, ed. G.P. Maggioni (Firenze: SISMELEdizioni del Galluzzo/Milano: Biblioteca Ambrosiana 2007), at p. 926.

3. Giovanni Paolo Maggioni, 'La Vita sanctae Theodorae (BHL 8070). La revisione imperfetta di una traduzione perfettibile', Hagiographica, 7 (2000), 20I-268. See p. 252: 'Et accurrens inuenit hominem comedentem a bestia et apprehendens bestiam a faucibus eius detulit hominem...'.

4. A recent article by Giovanni Orlandi is now an indispensable contribution on this topic: Giovanni Orlandi, 'Errore, corruttela, innovazione', Filologia Mediolatina, I 5 (2008), I-I8, repr. in Scritti di filologia mediolatina (Firenze: SISMEL, 2008), pp. 233-347. In the article, Orlandi distinguishes between error, corruption and innovation in the textual history.

5. In other words, lectiones constrasting with the linguistic norms and the general knowledge of author's cultural environment.

6. Cf. Orlandi, 'Errore corruttela, innovazione', p. 234: "In realtà la distinzione tra errore e innovazione attiene fondamentalmente al punto di vista da cui si pone l'osservatore: errore è un dato negativo che però dovrebbe permettere di risalire, stadio per stadio, all'archetipo ed eventualmente all'originale; innovazione è un dato positivo per chi si interessi alla storia del testo e ai suoi sviluppi. Accanto al termine errore qui si è inserito anche il termine 'corruttela', il quale, pur nella prospettiva ricostruttiva dell'edizione critica tradizionale, appare più neutro e quindi, a mio gusto, preferibile all'altro. Per errore difatti può intendersi qualcosa che vada oltre e contro gli intenti stessi del copista e del tipografo, un lapsus, una disattenzione, un fraintendimento del proprio modello".

7. Paul Maas, Textkritik (Leipzig: B. G. Teubner, I 957). See also Elio Montanari, La critica del testo secondo Paul Maas. Testo e commento (Firenze: SISMEL, 2003).

8. See Sebastiano Timpanaro, La genesi del metodo del Lachmann (Padova: Liviana I $985^{2}$ ); Giovanni Fiesoli, La genesidellachmannismo (Firenze:SISMELEdizioni del Galluzzo, 2000); Giorgio Pasquali, Storia della tradizione e critica del testo (Milano: Mondadori, I974²).

9. I have dealt with this kind of errors in 'Autori distratti e redattori imprecisi. Microvarianti e capitoli fuori posto nel testo originale della Legenda aurea', Filologia Mediolatina, I5 (2008), 75-94, and in the introduction of Jean de 
Mailly, Abbreviatio in gestis sanctorum. Editio princeps (Firenze: Sismel Edizioni del Galluzzo, 20I3), pp. CXCVIII - 588. Giovanni Orlandi and M. Herren have dealt with knowledge, skills and work of authors and scribes in pre-Carolingian period: Giovanni Orlandi, 'Un dilemma editoriale: ortografia e morfologia nelle Historiae di Gregorio di Tours', Filologia Mediolatina, 3 (I996), 35-7I, Michael Herren, 'Is the Author Really Better than his Scribes?: Problems of Editing Pre-Carolingian Latin Texts', Ars Edendi Lecture Series, vol. II (Stockholm 2012), pp. 83-I05.

Io. On this topic see for example Leighton Durham Reynolds and Nigel Guy Wilson, Scribes and Scholars. A Guide to the Transmission of Greek and Latin Literature, 2nd edition (Oxford: Oxford University Press, I974).

I I. See, for example, the declared interventions of Marcus Tullius Cicero, as quoted by Pasquali, Storia della tradizione, pp. 397-400.

I2. Such is the case of the famous MS Hamilton, see Vittore Branca and Pier Giorgio Ricci, Un autografo del Decameron. (Codice Hamiltoniano 90), Opuscoli accademici 8 (Padova: C.E.D.A.M., I962).

I3. See Timpanaro, La genesi del metodo del Lachmann, p. 80.

I4. Edited in Karl Wessely, 'Zu den griechischen papyri des Louvre und der Bibliothèque nationale. II. Die Vita s. Theodorae', in Fünfzehnter Jahresbericht des K. K. Staatsgymnasiums in Hernals (Wien, I 889).

I 5. Edited in G.P. Maggioni, 'La Vita sanctae Theodorae (BHL 8070)', pp. 242-268.

I6. Ibid., par. I49.

I7. Ibid., par. I40.

I 8. Ibid., par. 26 .

I9. On this topic, see for example David d'Avray, Medieval Marriage Sermons: Mass Communication in a Culture without Print (Oxford: Oxford University Press, 200I).

20. About secretaries and their work, see Edmund Colledge, 'James de Voragine's Legenda sancti Augustini and its Sources', Augustiniana, 35 (I985), 28 I-3 I4; Antoine Dondaine, Secrétaires de saint Thomas, Rome (Publications de la Commission Leonine pour l'édition des oeuvres de saint Thomas d'Aquin 4).

2 I. Iacopo da Varazze, Legenda aurea, XCVII, 45, p. 750 : 'Quod cum audissent sanctus Martinus episcopus et Antipater proconsul...'.

22. Gregorius Turonensis, De gloria martyrum, Passio septem dormientium, ed. Bruno Krusch, MGH Script. rer. Mer. I, 2 (Hannover, I 885 ) pp. 397-403, at p. 40I: 'Viri autem apprehensum Malchum ducunt ad episcopum Marinum et ad praefectum urbis'. 
23. See the Passio [BHG I594] of Symeon Metaphrastes in PG I I5, col. $428-448$.

24. Iacopo da Varazze, Legenda aurea, XCVII, 45, p. 750 : 'Quod cum audissent sanctus Martinus episcopus et Antipater proconsul...'.

25. Passio Septem Dormientium [BHL 23 I 5], Biblioteca Casinensis (Monte Cassino, I877), p. 257: 'et Antipatum proconsulem'.

26. Iacopo da Varazze, Legenda aurea, CXXXVI, 55, p. I074: 'Si enim in magnete lapide hec esse uirtus dicitur ut annulos et festucas sibi copulet...'.

27. Hieronymus Stridonius, Commentarii in evangelium Matthaei, ed. David Hurst and Marc Adriaen (Turnhout: Brepols I969), I, 9, 9.

28. Iacopo da Varazze, Legenda aurea, CXXXVI, 3 I, p. I072: 'In qua (scil. ecclesia magna) apostolus triginata annis et tribus sedit et totam Egyptum ad deum conuertit'.

29. Iacopo da Varazze, Legenda aurea, CXIX, 89, p. 926: 'Anno autem domini CCCXXXI Saraceni Siciliam inuadentes Liparitanam insulam ubi corpus sancti Bartholomei quiescebat uastauerunt...'.

30. See for example Giovanni Paolo Maggioni, 'Il codice novarese di Jean de Mailly e la “ Legenda aurea”, Novarien, I7 (I987), pp. I73-I 84.

3. Jean de Mailly, Abbreviatio, Io, 2-4: 'Nam cum esset sterilis miraculose habuit de Ioachim unam filiam Mariam matrem domini que fuit uxor Ioseph Require de hoc in natiuutate beate Marie -. Mortuo autem pimo marito...'.

32. Jean de Mailly, Abbreviatio, I44, 23: 'Post longus tempus scilicet anno domini cum sancti sua corpora Theodoro Augustodunensi episcopo reuelassent...'.

33. Jean de Mailly, Abbreviatio, I69, I: 'Martinus papa propter fidem Christi anno domini CCCL Ab imperatore Constantino de ecclesia raptus et perductus Constantinopolim relegatus apud Cersonam Lycie prouincie ibidem uitam finiuit, multis in eodem loco uirtutis signis usque hodie refulgens'.

34. We have two autographs of this chronicle in the MS Paris, BnF, Paris. lat. I4593. A partial edition is edited by George Waitz in MGH Script. XXIV (Hannover I 879), pp. 502-526.

35. Jacobi a Voragine, Legenda aurea vulgo Historia Longobardica dicta, ed. Theodore Graesse (Leipzig, I 850 ), p. 832.

36. Jacobus de Voragine, The Golden Legend: Readings of the Saints, trans. by William Granger Ryan, 2 vols (Princeton: Princeton University Press I993), vol. 2, p. 374 .

37. Iacopo da Varazze, Legenda aurea, pp. I000-1003. 
38. Ibid., vol. 2, pp. I45-I 47 .

39. See Giovanni Paolo Maggioni, Ricerche sulla composizione e sulla trasmissione della «Legenda aurea», Biblioteca di Medioevo latino, 8 (Spoleto: Centro Italiano di Studi sull'Alto Medioevo I995), pp. I37-I39.

40. Iacopo da Varazze, Legenda aurea, pp. 2I4-23 I.

4I. Bartolomeo da Trento, Liber epilogorum in gesta sanctorum, ed. Emore Paoli (Firenze: SISMEL - Edizioni del Galluzzo, 200I), pp. I4I-I42.

42. Iacopo da Varazze, Legenda aurea, pp. I I00-1 I03.

43. 'Vita sancti Fursei', ed. Maria Pia Ciccarese, Romano Barbarica, 8 (I984I985), pp. 279-303.

44. Iacopo da Varazze, Legenda aurea, pp. I I64-I I65.

45. About Saint Marina, see Evelyne Patlagean, 'L'Histoire de la femme deguisée en moine et la evolution de la sainteté feminine à Byzance', Studi Medievali, I7 (IIIs.) (I976), pp. I 595-I623; Vie et office de Sainte Marine, ed. Léon Clugnet et al. (Paris: Picard et fils, I905); Alfons Hilka, 'Une vie inédite de Sainte Marine', Analecta Bollandiana, 46 (I928), 67-68; Bibliotheca Sanctorum VIII (Roma: Istituto Giovanni XXIII della Pontificia Università lateranense, I965), cols II 65-II70.

46. Iacopo da Varazze, Legenda aurea, pp. 690-695.

47. Bartolomeo da Trento, Liber epilogorum, pp. I83-184.

48. Jean de Mailly, Abbreviatio, pp. 42 I-425.

49. Ibid., I 54, 64, p. 424: 'Vitam cuiusdam uirginis non minus dignam miraculo legimus quam propter morum et nominum similitudinem breuiter hic notamus'.

50. Bartolomeo da Trento, Liber epilogorum, p. 266: 'Digitus vero cum quo Dominum ad se venientem demonstravit illuc inter cetera fuir translatus; quem sancta Tecla inter Alpes attulit et dicitur esse in ecclesia Mauriana'.

5 I. Iohannes Beleth, Summa de ecclesiasticis officiis, ed. Henri Douteil, Corpus Christianorum CM 4I-4IA (Turnhout: Brepols I976), p. I47.

52. Gregorius Turonensis, De gloria martyrum, I, I4.

53. Sigebertus Gemblacensis, Chronicon, MGH Script. VI, ed. Ludwig Conrad Bethmann (Hannover I 844), p. 32 I.

54. Jean de Mailly, Abbreviatio, pp. 355-356: 'Anno domini DCXI sub Eraclio anno primi imperii eius uirtus et nomen sancti Iohannis baptiste miraculis declaratur apud urbem Galliem Mauriennam de reliquiis corporis ipsius hoc modo diuinitus illustratam. In ea olim mulier sancto baptiste nimis deuota expetebat a deo donari 
sibi aliquid de membris eius; et in hac orando instantia per triennium existens cum alter quiuis desperare iam posset ipsa spem in deo ponens iurauit se non manducaturam donec quod peteret acciperet. Et sic septem diebus ieiunans septima tandem die desuper altari pollicem miri candoris apparere uidens letam donum dei accepit'.

55. Iacopo da Varazze, Legenda aurea, I 2 I, pp. I 53-I 59 and I60-I63, p. 982. 56. Bibliotheca Sanctorum VI, col. 754.

\section{Bibliography}

\section{Primary Sources}

Bartholomaeus Tridentinus (Bartolomeo da Trento), Liber epilogorum in gesta sanctorum, ed. Emore Paoli (Firenze: SISMEL - Edizioni del Galluzzo, 200I)

Bibliotheca Sanctorum I-XII (Roma: Istituto Giovanni XXIII della Pontificia Università Lateranense. Città nuova, I96I-I970)

Follett, Ken, I pilastri della terra (Milano: Mondadori, I990)

Iacobus de Voragine (Iacopo da Varazze), Legenda aurea, ed. G.P. Maggioni (Firenze: SISMEL-Edizioni del Galluzzo/Milano: Biblioteca Ambrosiana, 2007)

Iacobus de Voragine, Legenda aurea vulgo Historia Longobardica dicta, ed. Theodore Graesse (Leipzig, I 850 )

Iacobus de Voragine (James de Voragine), The Golden Legend: Readings of the Saints, trans. by William Granger Ryan (Princeton: Princeton University Press, I993)

Gregorius Turonensis, De gloria martyrum, ed. Bruno Krusch, MGH Script. rer. Mer. I.2 (Hannover, I 885 )

Hieronymus Stridonius, Commentarii in evangelium Matthaei, ed. David Hurst and Marc Adriaen, Corpus Christianorum SL 77 (Turnhout: Brepols, I969)

Iohannes Beleth, Summa de ecclesiasticis officiis, ed. Henri Douteil, Corpus Christianorum CM 4I-4IA (Turnhout: Brepols, I976)

Iohannes de Mailliaco (Jean de Mailly), Abbreviatio in gestis sanctorum. Editio princeps, ed. Giovanni Paolo Maggioni (Firenze: SISMEL - Edizioni del Galluzzo, 2013)

Iohannes de Mailliaco, Chronica Universalis Metensis, Paris, BnF, ms. lat. I4593: exc. ed. George Waitz in MGH Script. XXIV (Hannover, I879)

Passio Septem Dormientium [BHL 23I5], Biblioteca Casinensis (Monte Cassino, I877), pp. 252-256 
Sigebertus Gemblacensis, Chronicon MGH Script. VI, ed. Ludwig Conrad Bethmann (Hannover I 844)

Symeon Metaphrastes, Passio Septem Dormientium (BHG I 594), PG I I 5 , cols $428-448$

Vie et office de Sainte Marine, ed. in Clugnet, Léon et al. (Paris: Picard et fils, 1905)

Vita Theodorae (BHL 8070), ed. G.P. Maggioni, 'La Vita sanctae Theodorae (BHL 8070). La revisione imperfetta di una traduzione perfettibile', Hagiographica, 7 (2000), pp. 20I-268

\section{Secondary Literature}

Branca, Vittore and Ricci, Pier Giorgio, Un autografo del Decameron. (Codice Hamiltoniano 90), Opuscoli accademici 8 (Padova: C.E.D.A.M., I962)

Colledge, Edmund, 'James de Voragine's Legenda sancti Augustini and its Sources', Augustiniana, 35 (I985), 28 I-3I4

d'Avray, David, Medieval Marriage Sermons: Mass Communication in a Culture without Print (Oxford: Oxford University Press, 200I)

Dondaine, Antoine, Secrétaires de saint Thomas, Publications de la Commission Leonine pour l'édition des oeuvres de saint Thomas d'Aquin, 4 (Rome, I956)

Fiesoli, Giovanni, La genesi del lachmannismo (Firenze: SISMEL, 2000)

Herren, Michael, 'Is the Author Really Better than his Scribes? Problems of Editing Pre-Carolingian Latin Texts', Ars Edendi Lecture Series, vol. 2, ed. by Alessandra Bucossi and Erika Kihlman (Stockholm, 20I2), 83-105

Hilka, Alfons, 'Une Vie inédite de Sainte Marine', Analecta Bollandiana, 46 (1928), 68-77

Maas, Paul, Textkritik (Leipzig: B. G. Teubner, I957)

Maggioni, Giovanni Paolo, 'Il codice novarese di Jean de Mailly e la "Legenda aurea"', Novarien, I7 (I987), I73-I 84

Maggioni, Giovanni Paolo, Ricerche sulla composizione e sulla trasmissione della «Legenda aurea», Biblioteca di Medioevo latino 8 (Spoleto: Centro Italiano di Studi sull'Alto Medioevo, I995)

Maggioni, Giovanni Paolo, 'La Vita sanctae Theodorae (BHL 8070). La revisione imperfetta di una traduzione perfettibile', Hagiographica, 7 (2000), I 27-I94

Maggioni, Giovanni Paolo, 'Autori distratti e redattori imprecisi. Microvarianti e capitoli fuori posto nel testo originale della Legenda aurea', Filologia Mediolatina, I 5 (2008), 75-94 
Montanari, Elio, La critica del testo secondo Paul Maas. Testo e commento (Firenze: SISMEL, 2003)

Orlandi, Giovanni, 'Un dilemma editoriale: ortografia e morfologia nelle Historiae di Gregorio di Tours', Filologia Mediolatina, 3 (I996), 35-7 I

Orlandi, Giovanni, 'Errore, corruttela, innovazione', Filologia Mediolatina, I 5 (2008), I-I 8

Orlandi, Giovanni, Scritti di filologia mediolatina (Firenze: SISMEL, 2008)

Giorgio Pasquali, Storia della tradizione e critica del testo (Milano: Mondadori I $974^{2}$ )

Patlagean, Evelyne, 'L'Histoire de la femme deguisée en moine et l'évolution de la sainteté feminine à Byzance', Studi Medievali, I7 (IIIs.) (I976), I 595-I 623

Reynolds, Leighton D. and Nigel G. Wilson, Scribes and Scholars. A Guide to the Transmission of Greek and Latin Literature, 2nd edition (Oxford: Oxford University Press, I974)

Sebastiano Timpanaro, La genesi del metodo del Lachmann (Padova: Liviana I $985^{2}$ )

Karl Wessely, 'Zu den griechischen papyri des Louvre und der Bibliothèque nationale. II. Die Vita s. Theodorae', in Fünfzenter Jahresbericht des K. K. Staatsgymnasiums in Hernals (Wien, I889) 